\title{
Susceptibility Evaluation of Debris Flow in Middle and Lower Reaches of Bailong River Based on Source Features
}

\author{
Gaofeng Wang ${ }^{1}$, Yuntao Tian ${ }^{1}$, Qing Yang ${ }^{1}$, Ning Guo ${ }^{1}$, Bing Deng ${ }^{1}$,Yupeng Ren $^{2}$, \\ Youlong Gao ${ }^{1}$ \\ ${ }^{1}$ Center for Hydrogeology and Environmental Geology Survey, China Geology Survey, Baoding \\ 071051, China \\ ${ }^{2}$ China University of Geosciences(Beijing), Water Resources and EnvironmentInstitute,Beijing \\ 100083, China
}

\section{基于物源特征的白龙江中下游 泥石流易发性评价 \\ 王高峰 ${ }^{1}$, 田运涛 ${ }^{1}$, 杨强 ${ }^{1}$, 郭宁 ${ }^{1}$, 邓兵 ${ }^{1}$, 任玉鹏 ${ }^{2}$, 高幼龙 ${ }^{1}$ \\ ${ }^{1}$ 中国地质调查局水文地质环境地质调查中心, 保定 071051 , 中国 \\ ${ }^{2}$ 中国地质大学 (北京) 水资源与环境学院, 北京 100083 , 中国}

\section{Abstract}

Debris flow susceptibility evaluation is the prerequisite for risk assessment, important basis for disaster prevention and mitigation work. Based on the field investigation of the debris flow disaster in the middle and lower reaches of the Bailong River, four evaluation factors of aspect, lithology, structure density and seismic density were selected based on the characteristics of debris flow source development. Using deterministic model and gray relation method was used to evaluate the sensitivity of debris flow source. Finally, the factors of source sensitivity, degree of erosion on the slop surface, grove gradient and gully density were selected from the top two terrain and provenance conditions of debris flow. The AHP model was used to analyze the regional debris flow susceptibility Zoning. The results showed that: $59.06 \%$ of the debris flow source distribution and $52.03 \%$ of the debris flow
\end{abstract}

ditch are located in the high-prone area, $85.62 \%$ of the debris flow source distribution and $81.76 \%$ of the debris flow ditch is located in the area above the medium-prone area, and the ratio of debris flow area and the source area b/a also increases. It shows that the susceptibility calculation of debris flow based on the analytic hierarchy process is in good agreement with the actual situation, and the result is more ideal. The evaluation results can provide reference for disaster prevention and mitigation in the project construction and town planning in the region.

Keywords: Bailong River; Debris flow; Susceptibility evaluation; Source

摘要

泥石流易发性评价是风险评价的前提, 是防灾减灾工作的重要依据。在对白龙江 流域中下游泥石流灾害进行实地调查的基 
础上, 首先依据泥石流物源发育特点, 选 取坡向、地层岩性、构造密度、地震密度 4 个评价因子, 采用确定性模型与灰色关联 组合方法, 进行泥石流物源敏感性评价。 最后从形成泥石流最为本底的地形和物源 两大孕灾条件分析, 笁选出物源敏感性、 坡面侵蚀程度、沟床比降、沟壑密度等因 子, 运用 AHP 模型进行区域泥石流易发性 区划。结果表明： $59.06 \%$ 的泥石流物源分 布和 $52.03 \%$ 的泥石流沟处于高易发区以上 地区， $85.62 \%$ 的泥石流物源分布和 $81.76 \%$ 的泥石流沟处于中易发区以上地区，同时 泥石流流域物源面积的比率 b/a 也随之增大。 说明以层次分析法为基础的泥石流易发性 计算结果与实际情况比较吻合, 划分结果 较为理想, 评价结果可为该区域工程建设 及城镇规划提供防灾减灾参考依据。

关键词: 白龙江流域; 泥石流; 易发性评 价; 物源

\section{1. 引言}

据研究白龙江流域是甘肃省滑坡、泥 石流分布密度最大、发生频率高、灾害最 为频繁的地区, 亦是我国泥石流地质灾害

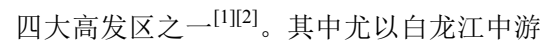
最为严重, 自舟曲县城至福津河口段, 两 岸为千枚岩主要出露区、植被稀少, 是白 龙江流域泥石流分布最为集中、群发性灾 害最为频繁、致灾最严重的地段, 有较大 和潜在危害的泥石流沟多达 40 条 $^{[3]}$ 。近年 来, 随着人类工程活动对地质环境影响作 用的强烈扰动, 流域内松散物源及随意堆 放的工程弃渣在雨水作用下极易参与泥石 流活动。加上白龙江流域中下游地处地质 构造复杂且强震多发区、岩体为易崩易滑 较为破碎区, 这些易形成泥石流的物源, 且在后期极端强降雨条件下产生及聚集方 式将发生不同程度的变化, 此外大坡降深 切峡谷地貌形态、半干旱和极端强降水区 耦合响应的气象条件及多阶梯植被分带特 征, 很容易造成泥石流发生。该流域段物 源表现为: 在下游硬岩区具有“裂”而未“滑”、 “松”而未“动”的隐蔽性, 泥石流灾害特征表 现为“低频突发性”; 而在中游软岩区则为
“单位面积储量大、动储量逐渐增多”的暴露 性, 灾害特点表现为“高频群发性”。该段重 特大泥石流灾害具有反复发作及潜在爆发 的可能, 故对白龙江流域中下游泥石流物 源发育特征、启动规律研究有利于泥石流 的认识和工程防治, 及基于物源特征的区 域泥石流易发性快速评价对土地规划利用 具有指导意义。

泥石流易发性评价是风险评价的前提, 是指在一定的临界诱发条件下容易发生泥 石流的可能性大小, 泥石流易发性是基于 其地质地貌等孕灾背景条件进行分析评价, 进而预测评价区域未来产生泥石流灾害的 可能性。由于泥石流的孕育是个十分复杂 的过程, 受不确定因素影响较多。从上世 纪 70 年代国内外专家对泥石流评价的发展 主要体现在对评价指标的篮选简化及评价 方法的优化, 在泥石流易发性评价方面作 出了大量的研究, 取得了丰富的成果, 如 信息量法 ${ }^{[4]}$ 、AHP 层次分析法 ${ }^{[5]}$ 、证据权法

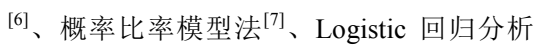
法 $^{[8]}$ 等 Gao 等 ${ }^{[9]}$ 重点总结了泥石流危险性评 价的三类方法: 统计学方法、基于数值模 拟、结合 $3 \mathrm{~S}$ 技术的泥石流危险性评价方法, 并分析了泥石流危险性评价工作的发展趋 势。以上研究成果不论在评价方法还是模 型构建都很大程度上推动了泥石流灾害易 发性评价的发展, 但由于评价对象地域的 差异和目标的不确定性, 这些方法也存在 一定的局限和不足, 特别在评价因子的选 取上多采用他人的成果且评价因子具有重 复性, 依据泥石流物源发育特征对参评因 子进行分析却鲜有报道, 这是目前区域泥 石流易发性评价研究工作的一个亟待解决 的问题。本文依据白龙江中下游泥石流特 定的孕灾环境对参评因子进行分析, 着重 强调泥石流物源发育特征, 选取具有科学 性、易获取和重复性小的评价因子, 运用 层次分析法建立区域泥石流易发性评价模 型, 评价结果可为该区域工程建设、泥石 流群测群防 ${ }^{[10]}$ 及城镇防洪 ${ }^{[11]}$ 规划提供防灾 减灾参考依据。 


\section{2. 泥石流物源孕灾环境及类型}

\section{1 泥石流物源孕灾环境}

研究区面积 $2072.9 \mathrm{~km}^{2}$, 主要位于白龙 江流域甘肃段中下游，包括白龙江干流武 都区石门乡至文县临江镇段及其支流蒲池 河、北峪河下游、福津河、龙坝河、羊汤 河。在地形地貌上地处青藏高原东部、秦 岭山地西缘, 属典型的深切峡谷地貌, 区 内泥石流流域具有比降陡、沟谷中后缘形 态多呈大肚子状的特点，不仅易于水流汇 聚, 而且物源极为丰富。地质构造上地处 松潘-甘孜褶皱带和南秦岭褶皱带两个不同 构造体系的交接部位, 研究区南北两端受 构造运动活动极为强烈, 北部属武都山字 型构造西翼白龙江复背斜南端, 主要受 NWW 向的白龙江断裂和光盖山迭山断裂、 $\mathrm{NE}$ 向礼县-罗家堡断裂、近 $\mathrm{E}$ 向两当-江洛 断裂影响, 南部主要受哈南-青山湾-稻畦子 断裂及文康断裂影响, 受以上断裂的影响 导致岩体变形破碎, 为泥石流提供丰富的 松散物质，此外该区复杂的构造又为泥石 流发育提供了良好的地形条件 ${ }^{[12]}$ 。同时, 该段位于我国南北地震带中北段, 历次地 震活动加剧了山体和岩土结构破坏及其他 地质灾害的发生, 导致松散物源剧增, 诱 发一系列新的泥石流等地质灾害。该区地 层岩性极为复杂, 属西秦岭地层区, 从前 震旦系到第四系均有出露, 分布最为广泛 的地层为泥盆系、志留系、石炭系和侏罗 系, 其中尤以泥盆系和志留系地层分布最 为广泛, 岩性强度较低, 多属软弱岩层, 易受降雨侵蚀、构造破坏和风化剥蚀（图 1)。

气候上白龙江中游属暖温带向亚热带 过度区, 降雨垂向上随海拔增高具有增大 的规律, 常以连阴雨、暴雨形式出现。受 山地气候及地形的影响, 研究区降水具有 时空分布不均、年内分配差异性较大的特 征, 降水具有由南向北递减趋势且局地小 气候现象明显。据前人研究降雨在一日之 内亦有不同, 在同一泥石流沟域也存在差 异性 ${ }^{[13]}$ 。

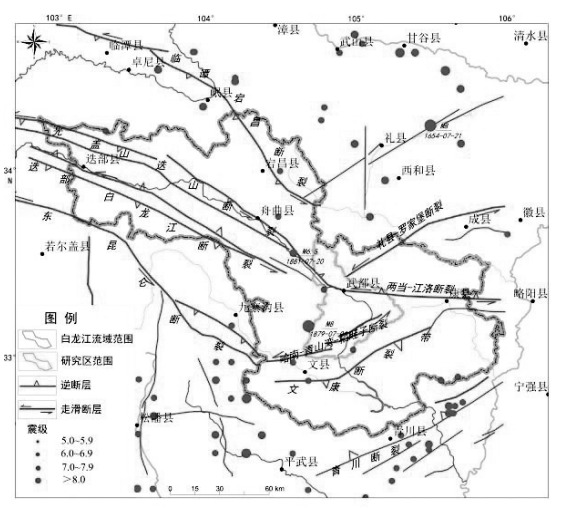

图 1 研究区活动构造与地震分布图

\section{2 泥石流物源类型分析}

研究区泥石流物源主要为破碎岩体、 松散黄土层、第四系松散堆积物和人工弃 渣, 物源总面积总计 $152.61 \mathrm{~km}^{2}$, 占研究区 面积的 $7.25 \%$ 。

其中破碎岩体高程位置上分布在泥石 流沟分水岭地带及地形突变区, 以碎裂状、 片状、碎屑状为主斜坡岩体, 易产生滑坡 成为泥石流细颗粒物质的主要物源类型, 而岩体以碎块状为主斜坡, 形状似“豆腐块” 披覆或悬挂于坡体, 常以崩塌的形式出现 堆积于沟道, 成为泥石流发生的粗颗粒物 质的主要物源。在地震作用下碎裂岩体, 容易形成微裂隙或大型拉张裂缝, 而后降 雨不断扰动, 在软硬接触面或软弱风化壳 或断裂破碎带形成易滑、易崩面, 最终导 致碎裂岩体后缘拉裂、前缘临空、基座支 撑力降低, 产生崩滑或滑坡 ${ }^{[14]}$ 。这些物质 常以“碎裂效应”的方式成为过渡性泥石流物 质的主要来源, 常形成胶结强度大、呈叠 瓦式镶嵌的泥石流堆积体。

松散黄土层指支离破碎黄土层及类黄 土层, 前者主要岩性为马兰粉砂质黄土, 结构松散, 垂直节理、落水洞发育, 后者 为经后期改造含有碎石的黄土类土, 以粉 砂质黄土为主, 夹杂粒径多在 $0.5 \sim 2 \mathrm{~cm}$ 的碎 石, 胶结程度好, 多凌乱堆积于老滑坡堆 积体之上, 冲沟发育, 该类物源在降雨作 用下坡表冲蚀严重, 沟壑淋漓, 呈现“坡扒 皮”形状, 故常以“剥蚀效应”诱发浅层滑坡。 
第四纪松散堆积物包括洪积物、残坡 积物及滑坡崩塌堆积物。洪积物一般位于 泥石流沟沉积区及流通区沟床, 厚度 3 60m 不等, 结构松散, 骨架式堆积, 固 相颗粒呈棱角状 次棱角状, 一般成层性好, 单层分层明显, 成次分明, 颗粒间多充填 粉砂质黄土及砂砾, 透水性较强, 受前次 泥石流影响老泥石流堆积体中细颗粒被带 走, 残留大颗粒块石可增强下次大规模泥 石流爆发铲刮沟底物源动力, 这些物质以 “承轴效应”参与泥石流活动。残坡积物多位 于泥石流沟边坡表层, 由强风化千枚岩、 页岩、炭质板岩等软弱的块碎石土组成, 一般厚 $0.5 \sim 5 \mathrm{~m}$, 粒径大小多在 $2 \sim 10 \mathrm{~cm}$ 之 间, 棱角状, 粒间充填细小颗粒及粘土, 透水性较好, 坡面易被雨水冲蚀呈“猫爪脸” 凹槽形状, 雨水作用下斜坡前缘垮塌或溜 滑, 坡体表面出现剪切拉槽式“剥皮效应”, 后缘拉裂等变形迹象, 可成为下次泥石流 的可动物源 ${ }^{[15]}$ 。滑坡堆积物一般在泥石流 源头及流通区两岸, 厚度一般在 6 30m, 个别可达到近 $45 \mathrm{~m}$, 固体颗粒粒径一般在 $5 \sim 20 \mathrm{~cm}$ 之间, 局部为大块石, 直径可达 $6.5 \mathrm{~m}$, 多呈棱角状, 透水性较好, 以“碎化 冲蚀效应”补给泥石流。

人工弃渣主要有以下几个方面: 坡地 绿化, 消坡整平坡地, 随意性沿坡面泄流 于坡表进而堆积于沟道, 雨水作用下, 坡 表不断侵蚀、冲刷, 形成细沟, 坡脚不断 侵润, 可形成局部滑动或上推下拉式整体 滑移破坏, 经数次雨水强烈冲刷下, 细沟 不断扩大加深, 在极端强降雨作用下, 底 部润滑式支撑面形成滑动面, 造成失稳破 坏, 更有甚至在破坏过程中带动强风化破 碎基岩表层滑动。开山修路, 使其弃渣粗 放式堆放于陡坡坡表, 形成坡面浅表层物 源, 在自然重力作用、雨水冲刷和坡面渗 流作用下, 弃渣时常失稳发生崩滑或坡面 泥石流, 沿着斜坡逐渐或突发式堆积于坡 脚。铁路修建隧道开挖弃 (土) 渣合理性 堆放于沟口开阔处或堆积于沟道宽缓处, 堆积厚度数米至数十米不等, 当堆积厚度 小于 $5 \mathrm{~m}$, 在洪水作用下易造成揭底, 堆积 厚度大于 $5 \mathrm{~m}$ 时, 在雨水的不断冲刷和坡面
逐渐渗流作用下, 容易发生滑坡, 亦可能 产生碎屑流动。

\section{3 区域泥石流易发性评价分析}

\section{1 易发性评价因子确定}

在评价区域泥石流易发性时因子的选 取主要考虑最为本底的孕灾因子条件。故 从泥石流形成需要三个基本条件之地形和 物源入手即: 丰富的固体松散物质来源、 利于泥石流发生的地形条件。本文在结合 白龙江流域中下游自然地理特征和资料可 获得性的基础上, 选取了获取简单、操作 便捷、因子重复性小的物源敏感性、沟床 比降、沟壑密度和坡面侵蚀程度等 4 个的区 域泥石流评价因子。

物源敏感性因子 $\left(\mathrm{B}_{1}\right)$ : 流域内发育的 丰富松散固体物质是泥石流发生的必要条 件, 它是导致泥石流发生规模的最直接的 因素, 没有大量的岩石破坏产物, 就不可 能形成泥石流 ${ }^{[16]}$, 因此松散固体物质储量 越大, 泥石流发生的可能性也就越大。根 据上述笔者选取断裂构造密度、地震活动 性密度、地层岩性及坡向进行区域物源敏 感性评价。

坡面侵蚀程度因子 $\left(\mathrm{B}_{2}\right)$ : 反映流域坡 表的直接破坏程度, 是人类活动、土壤可 侵蚀程度及地形地貌等多因素综合体现的 结果, 为综合性的山地孕灾因子, 并在特 殊的地质地貌环境条件下会诱发泥石流等 地质灾害, 在运动特征上可表现为侵蚀产 沙、泥沙搬运及堆积。参考前人取得的成 果及数据参数 ${ }^{[17]}$, 基于 GIS 的 Spatial Analyst 功能下分析坡面侵蚀在土壤可蚀性 因子 $(K)$ 、地形因子 $(L S)$ 及植被覆盖与 水土保持措施 $(C P)$ 因子叠加运算得出研 究区坡面侵蚀程度因子分区图。

沟床比降因子 $\left(\mathrm{B}_{3}\right)$ : 是泥石流地形势 能因素的综合体现, 亦是判别泥石流搬运 沟道物质难易程度的指标, 沟床纵坡降越 大, 降水会在短时间内迅速集中并形成高 速水流, 动能迅速升级, 加强侵蚀和挟带 能力, 使泥石流能在短时间内形成且流速 较快, 随着纵坡降的增大, 地表物质的稳 定性相对减弱, 在水动力条件的激励作用 
下参与泥石流活动。沟床比降为沟谷高差 与主沟道长度的比值, 该指标可在 ARCgis 平台下提取评价区域的河（沟）谷网格（5 $\times 5 \mathrm{~km}$ ) 和地形起伏度, 然后在 Spatial Analyst 下的栅格计算器求得沟床比降分区 图。

沟壑密度因子 $\left(\mathrm{B}_{4}\right)$ : 是水流汇集能力 的表现, 流域沟壑密度在一定程度上反映 了该地区地形切割程度、起伏程度和岩土 体松散程度, 亦能反映土壤侵蚀的严重程 度, 也能反映地貌的演化阶段。沟壑密度 采用泥石流流域范围内沟壑线密度来表达, 即单位面积内沟壑线的总长度, 然后以精 度为 $30 \times 30 \mathrm{~m}$ 的 DEM 数据为基础, 首先生 成 $5 \mathrm{~km} \times 5 \mathrm{~km}$ 网格, 然后利用 GIS 中的分析 功能, 将研究区内泥石流流域内沟壑线状 因子与网格相交、重新统计总长度、连接 等操作, 最后得到沟壑密度因子图。

\section{2 因子权重及评价方法}

\subsection{1 泥石流物源敏感性因子权重及评价方}

\section{法}

物源分布主要通过对研究区进行野外 1:5 万精度地面调查结合室内多期遥感数据 解译 (主要解译泥石流流域形成区物源) 统计得出。综合分析导致泥石流物源形成 的孕灾背景条件, 参考前人研究成果 ${ }^{[18]}$ 根 据公式 (1) 确定研究区重点 32 条泥石流 流域内所有物源类型在地形要素 (坡向因 子, 而坡度及坡高因子与评价泥石流易发 性其他三因子重复, 此处物源敏感性评价 时不考虑)、地质要素 (包括地层岩性因子、 地震活动性因子及断裂、断层分布因子) 共计 4 个评价因子在不同分级条件下的概率 综合判别值 $\mathrm{CF}$ 。

$$
C F=\left\{\begin{array}{l}
\frac{P P_{a}-P P_{s}}{P P_{a}\left(1-P P_{s}\right)} \text { 若 } P P_{a} \geq P P_{\mathrm{s}} \\
\frac{P P_{a}-P P_{s}}{P P_{s}\left(1-P P_{a}\right)} \text { 若 } P P_{a}<P P_{\mathrm{s}}
\end{array}\right.
$$

式中, $P P_{a}$ 为泥石流物源事件在分类

数据 $\mathrm{a}$ 中的发生概率 $(0 \sim 1)$ 用分类数据 $\mathrm{a}$ 中的泥石流物源面积与其面积的比值来表 示; $P P_{s}$ 表示为整个研究区内的物源发生 面积与研究区总面积的比值。CF 值的范围 为 $[-1,1]$, 正值代表泥石流流域物源易发 程度高, 即孕灾环境条件易于泥石流物源 的产生, 相反, 孕灾背景条件不易于泥石 流物源的产生。

以地层岩性因子为例, 在 arcgis 中编辑 工具下, 进行研究区 1:20 万地质图地层岩 性的矢量化工作, 进而将泥石流物源面积 分布与地层岩性开展叠加运算, 利用公式 （1）划分地层岩性因子下等级区间（表 1), 从表 1 得出研究区物源主要位于由千枚岩、 板岩组成的志留系及由泥岩与粉砂岩互层 组成的新近系, 极易受地震及外营力影响 产生易滑型滑坡; 其次为由千枚岩、含炭 板岩夹灰岩组成的泥盆系和由风积黄土、 老泥石流堆积物及崩滑堆积组成的第四系, 易在降雨条件下产生坡面水土流失和“坡扒 皮”溜滑, 再者由石英砂岩、片状砾岩及千 枚岩组成的碧口群地层系, 受地震的影响 产生易崩易滑松散堆积体, 这些为泥石流 的发生提供了丰富的物源条件。

然后通过对各评价因子的 $\mathrm{CF}$ 值重新整 合划定评价因子敏感性分区标准（表 2), 依据标准得到 32 条重点泥石流物源在 4 个 评价因子的分值, 得出各评价因子某一分 类数据对泥石流物源敏感性程度贡献大小 分区图 (图 3), 最后结合灰色关联法确定 物源敏感性评价因子权重, 从大到小依此 为地层岩性 0.3086 、坡向 0.2359 、地震密 度 0.2324 、构造密度 0.2224 , 建立研究区 泥石流物源敏感性评价分区图。 
表 1 研究区地层岩性分级及分级赋值

\begin{tabular}{ccccccc}
\hline 地层岩性分级 & 分级总面积 $/ \mathrm{km}^{2}$ & 物源面积 $/ \mathrm{km}^{2}$ & $\mathrm{PPa}$ & $\mathrm{PPs}$ & $\mathrm{CF}$ & 赋值 \\
\hline $\mathrm{Pz}$ 前震旦系 & 53.156 & 4.233 & 0.080 & 0.073 & 0.094 & 3 \\
$\mathrm{~S}$ 志留系 & 401.198 & 45.562 & 0.114 & 0.073 & 0.388 & 4 \\
$\mathrm{D}$ 泥盆系 & 952.398 & 73.373 & 0.077 & 0.073 & 0.061 & 3 \\
$\mathrm{C}$ 石炭系 & 213.677 & 4.695 & 0.022 & 0.073 & -0.713 & 2 \\
$\mathrm{P}$ 二叠系 & 51.251 & 0.003 & 0.000 & 0.073 & -0.999 & 1 \\
$\mathrm{~T}$ 三叠系 & 99.356 & 2.807 & 0.028 & 0.073 & -0.629 & 2 \\
$\mathrm{~J}$ 侏罗系 & 205.114 & 11.480 & 0.056 & 0.073 & -0.244 & 2 \\
$\mathrm{E}$ 古近系 & 8.128 & 0.000 & 0.000 & 0.073 & -1.000 & 1 \\
$\mathrm{~N}$ 新近系 & 37.304 & 5.444 & 0.146 & 0.073 & 0.541 & 4 \\
$\mathrm{Q}$ 第四系 & 82.835 & 5.381 & 0.065 & 0.073 & -0.114 & 3 \\
\hline
\end{tabular}

表 2 研究区物源敏感性评价因子分级及赋值

\begin{tabular}{|c|c|c|c|c|}
\hline 影响因子 & \multicolumn{4}{|c|}{ 因子分级范围 } \\
\hline 坡向/() & $\begin{array}{c}<45^{\circ}[\mathrm{NNE}] \\
325^{\circ} \sim 360^{\circ}[\mathrm{NN} \\
\mathrm{W}]\end{array}$ & $45^{\circ} \sim 90^{\circ}[\mathrm{NEE}]$ & $\begin{array}{c}135^{\circ} \sim 225^{\circ}[\mathrm{SSE} \sim \mathrm{SSW}] \\
\text { 、 } 270^{\circ} \sim 325^{\circ}[\mathrm{SWW}]\end{array}$ & $\begin{array}{l}90^{\circ} \sim 135^{\circ}[\mathrm{SEE}] 、 \\
225^{\circ} \sim 270^{\circ}[\mathrm{SSW}]\end{array}$ \\
\hline $\begin{array}{c}\text { 构造密度 } \\
\left(\mathrm{km} / \mathrm{km}^{2}\right. \\
)\end{array}$ & $<0.25$ & $0.25 \sim 0.35$ & $0.45 \sim 0.6$ & $0.35 \sim 0.45 、>0.6$ \\
\hline $\begin{array}{c}\text { 地震密度 } \\
\text { (处 } \\
\left./ \mathrm{km}^{2}\right)\end{array}$ & $2.2 \sim 2.8$ & 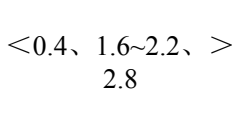 & $1.0 \sim 1.6$ & $0.4 \sim 1.0$ \\
\hline 地层岩性 & $\begin{array}{l}\mathrm{E} \text { 古近系、 } \\
\text { 叠系 }\end{array}$ & $\begin{array}{l}\mathrm{C} \text { 石炭系、 } \mathrm{T} \text { 三叠 } \\
\text { 系、 } \mathrm{J} \text { 侏罗系 }\end{array}$ & $\begin{array}{c}\mathrm{Pz} \text { 前震旦系、 } \mathrm{D} \text { 泥盆 } \\
\text { 系、 } \mathrm{Q} \text { 第四系 }\end{array}$ & $\begin{array}{l}\mathrm{N} \text { 新近系、 } \mathrm{S} \text { 志 } \\
\text { 留系 }\end{array}$ \\
\hline 贡献赋值 & 1 & 2 & 3 & 4 \\
\hline
\end{tabular}

本文研究采用 AHP 法为泥石流易发 性每个评价因子指标赋权重值进行评价。 AHP 是一种可以解决多指标的复杂问题、 定量与定性相结合的决策方法, 其优点是 具有精度高, 使用方便 ${ }^{[19]}$ 。具体步骤:

建立层次结构模型、构建成对比较矩 阵、计算权向量、一致性检验。本文共考 虑物源敏感性、坡面侵蚀程度、沟床比降、 沟壑密度共 4 个评价指标因子, 参考以往 研究资料 ${ }^{[20]}$ 对指标因子之间的相互重要 性进行打分, 并结合研究区的泥石流易发 性因子级别分级分析结果, 最终构建判断 矩阵 (表 3)。在 Matlab 软件下求得判断 矩阵的最大特征值 $\lambda_{\text {max }}=4.0014$, 一次性 指标 $C I=\left(\lambda_{\max }-n\right) /(n-1=(4.0014-4)$ / (4-1) $=0.0005$, 查平均随机一致性指标
该矩阵具有较好的判断一致性, 判断合理。 最大特征值对应的特征向量为 ( 0.7666,0.4979,0.3149,0.2555), 进行归 一化处理后即得到各个影响因子的权重 （表 3)。因子权重计算结果表明, 泥石 流物源敏感性是研究区内泥石流孕灾最严 重的因子, 接下来依次是坡面侵蚀程度、 沟床比降, 沟壑密度。

本文的易发性评价是在 GIS 平台下实 现的, 将各参评因子的分级赋值图层在 GIS 空间分析模块 Map Calculator 命令进 行加权叠加 (图 4), 可得到研究区泥石 流易发性评价栅格图层（图 5)。泥石流 易发性分级计算模型为:

$$
S=\Sigma W_{i} \times B_{i j}(2)
$$

式中: $S$ 为评价单元的综合易发程度值; $\mathrm{W}_{i}$ 为第 $i$ 个指标因子的易发程度权重; $\mathrm{B}_{i j}$ 为第 $i$ 个指标属性 $j$ 的易发性程度。 
表 3 易发性评价因子权重的配对比较矩阵

\begin{tabular}{cccccc}
\hline 因子 & $B_{1}$ & $B_{2}$ & $B_{3}$ & $B_{4}$ & $W_{i}$ \\
\hline$B_{1}$ & 1 & 1.5 & 2.5 & 3 & 0.418 \\
$B_{2}$ & $2 / 3$ & 1 & 1.5 & 2 & 0.271 \\
$B_{3}$ & $2 / 5$ & $2 / 3$ & 1 & 1.2 & 0.172 \\
$B_{4}$ & $1 / 3$ & $1 / 2$ & $5 / 6$ & 1 & 0.139 \\
\hline
\end{tabular}

注: $B_{1}$ 为物源敏感性因子; $B_{2}$ 为坡面侵蚀程度因子; $B_{3}$ 为沟床比降因子; $B_{4}$ 为沟獒密度因子; $W_{i}$ 为因子权重。

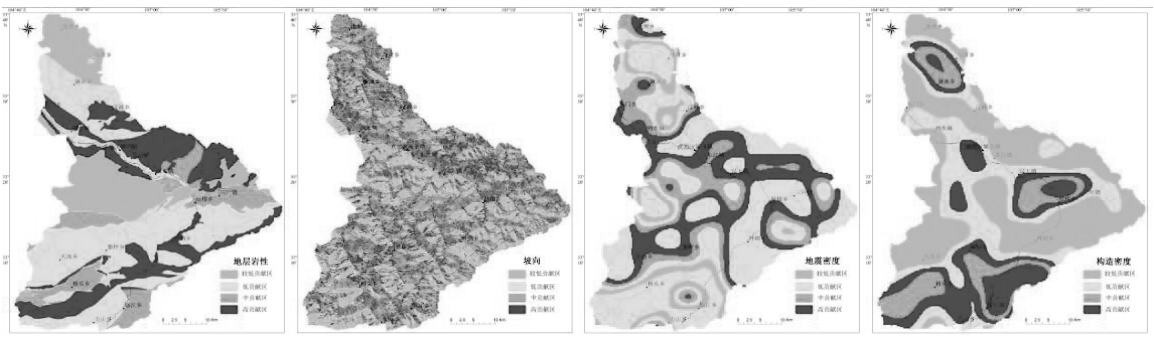

图 3 泥石流物源敏感性评价各因子贡献分级图

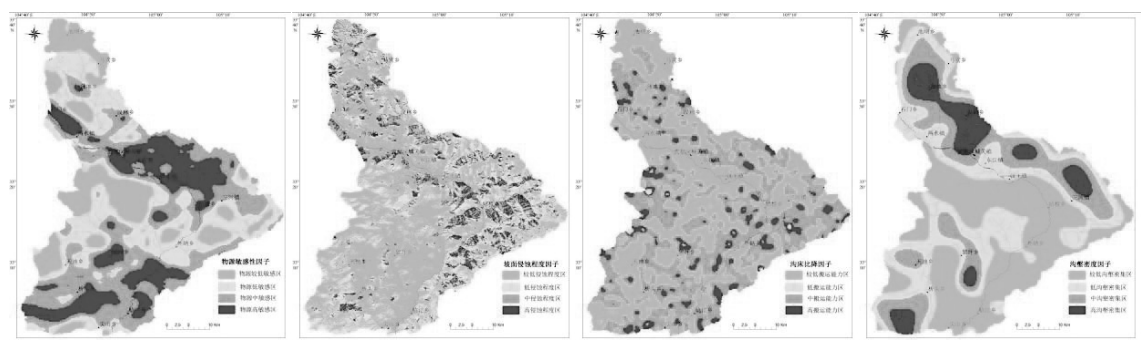

图 4 泥石流易发性评价各因子分级图

\section{3 区域泥石流易发性分区结果及检验}

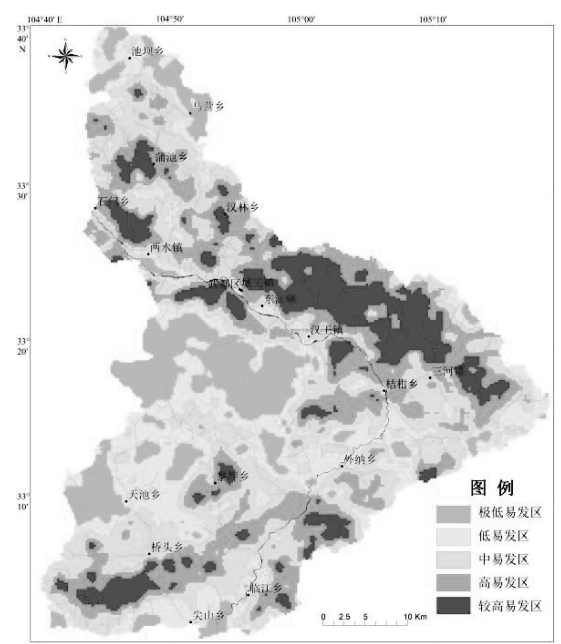

图 5 白龙江中下游泥石流易发性评价区划图
从图 5 空间位置上看, 泥石流极高易 发区主要分布在两水镇-蒲池乡、武都区-桔 柑乡段白龙江干流左岸、龙坝河中下游 （梨坪乡）、外纳乡下游至临江上游段即 白龙江左岸、桥头乡羊汤河中下游右岸及 三河镇瓦川河中游右岸。

泥石流高易发区主要分布在极高易发 区周边及汉林乡汉林沟流域、磨坝乡集镇 周边、福津河下游段及城郊乡-透坊沟白龙 江干流右岸段。泥石流易发性高的区域有 几个特点: (1)沿大型活动性断裂呈带状分 布, 在次级断裂和小型褶皱密集区集中发 育; (2)与地层岩性关系密切, 易发程度极 高的区域主要是由软弱千枚岩、炭质板岩 组成志留系一段及由灰岩、千枚岩互层构 成泥盆系四、五段易滑地层区, 而易发程 度高的区域主要是软硬相间组成的较坚硬 易崩地层区; (3)在沟壑密集带集中分块、 
分区发育; (4)在坡面侵蚀程强的区域多为 泥石流高易发区, 呈串珠状连片分布; (5) 研究区南北两侧泥石流易发性受控的影响 因子不同，泥石流性质亦有差异，北部主 要受控于软弱的易滑地层及 “山字型” 活 动性断裂影响, 多粘性泥石流; 而南部受 控于 $\mathrm{NE}$ 向断裂及地震影响, 山体松动多 易崩地层, 主要为稀性泥石流。

为检验泥石流易发性评价结果的合理 性, 基于物源分布数据及分析研究区 148 条泥石流沟易发特征与评价得出的易发性
等级区划图进行叠加, 提取每个级别的易 发程度值, 统计得到不同易发等级下的泥 石流物源面积及其面积占比和泥石流分布 密度 (表 4)。检验结果显示, $59.06 \%$ 的泥 石流物源分布和 $52.03 \%$ 的泥石流沟处于高 易发区以上地区， $85.62 \%$ 的泥石流物源分 布和 $81.76 \%$ 的泥石流沟处于中易发区以上 地区, 同时泥石流流域物源面积的比率 b/a 也随之增大。说明以层次分析法为基础的 泥石流易发性计算结果与实际情况比较吻 合, 划分结果较为理想。

表 4 白龙江中下游泥石流易发性评区划统计

\begin{tabular}{|c|c|c|c|c|c|c|c|}
\hline 易发等级 & $\begin{array}{l}\text { 各易发等级 } \\
\text { 面积 }\left(\mathrm{km}^{2}\right)\end{array}$ & $\begin{array}{l}\text { 各易发等级 } \\
\text { 占研究区面 } \\
\text { 积的 } \%(a)\end{array}$ & $\begin{array}{l}\text { 泥石流流 } \\
\text { 域物源面 } \\
\text { 积 }\left(\mathrm{km}^{2}\right)\end{array}$ & $\begin{array}{l}\text { 泥石流流域物源 } \\
\text { 面积占泥石流总 } \\
\text { 面积的\%(b) }\end{array}$ & $\begin{array}{l}\text { 泥石流 } \\
\text { 沟条数 } \\
\text { (处) }\end{array}$ & $\begin{array}{l}\text { 泥石流分布 } \\
\text { 密度(处/km²) }\end{array}$ & $\mathrm{b} / \mathrm{a}$ \\
\hline 极低易发区 & 275.76 & 13.10 & 4.83 & 3.16 & 6 & 0.022 & 0.24 \\
\hline 低易发区 & 451.92 & 21.47 & 17.11 & 11.21 & 21 & 0.046 & 0.52 \\
\hline 中易发区 & 594.69 & 28.25 & 40.53 & 26.56 & 44 & 0.074 & 0.94 \\
\hline 高易发区 & 520.51 & 24.73 & 51.21 & 33.56 & 41 & 0.079 & 1.36 \\
\hline 极高易发区 & 261.86 & 12.44 & 38.93 & 25.51 & 36 & 0.137 & 2.05 \\
\hline
\end{tabular}

\section{4 结论}

（1）研究区易崩易滑的地层岩性组合、 呈带状展布的大型活动性断裂构造及密集 发育的小型断层是泥石流最主要的孕灾条 件, 使该区具有物源集中成片分布、高易 发泥石流分布密度高、在较大沟谷间三角 面地带冲沟及大比降坡面泥石流成片发育、 区内北部泥石流较南部发育且多为粘性泥 石流。在进行泥石流易发性评价时首先分 析总结研究区物源类型、发育规律及转化 泥石流的方式。再结合泥石流物源特点, 选择影响物源发生发展的坡向、地层岩性、 地震密度、构造密度 4 个主要因子作为评价 因子, 尤其考虑到研究区受强烈地震扰动 这一因素, 加入了地震活动性密度进行区 域泥石流物源敏感性评价, 取得了较好的 结果。

(2) 通过参阅大量的前人文献资料和 精细化的野外实地调查, 依据评价因子少 而精、过程简而便、结果准而实用的原则, 选取了泥石流物源敏感性、坡面侵蚀程度、 沟床比降、沟壑密度 4 个参评因子, 对研究 区泥石流进行了易发性划分。白龙江中下 游属泥石流重度威胁区, 得出较为精准的
易发性分区结果, 能反映区内发生泥石流 可能性大小, 不仅能较为客观地对该区域 进行快速泥石流风险评价提供基础数据, 而且能为相关部门进行防灾减灾、监测预 警提供科学依据。本文在评价泥石流易发 性的过程中, 在确定因子权重时采用了 AHP 法, 虽然这种方法便捷, 但其权重确 定中不可避免地存在主观判别, 其合理性 还有待于进一步论证。

\section{Acknowledgements}

This study was supported by the Geological Surveyof China Geological Survey (DD20160281).

\section{致谢}

本研究得到了中国地质调查局地质调查项 目(DD20160281)的资助。

\section{参考文献}

[1] 王得楷,王靖泰.甘肃省滑坡泥石流述略, 甘肃科学学报, 1989,1(1): 64-69.

[2] 陈秀请,白福,于燕燕.甘肃省泥石流发育 
特征、成因分析及其危害, 西北地 质,2014,47(3):205-210.

[3] 王俊杰,孟少童,张继强,等.白龙江中游 千枚岩出露区泥石流生态修复原理与 技术集成, 甘肃林业科技,2015,40(1)：113.

[4] 岳溪柳,黄玫,徐庆勇,等.贵州省喀斯特 地区泥石流灾害易发性评价,地球信息 科学学报, 2015,17(11):1395-1403.

[5] 黎艳,陈剑,许冲,等.基于AHP的半干旱 区泥石流易发性评价: 以金沙江上游 奔子栏一昌波河段为例,现代地质, 2015, 29(4):975-982.

[6] 孟凡奇,李广杰,秦胜伍, 等.基于证据权 法的泥石流危险度区划, 吉林大学学报 (地球科学版) ,2010,40(6):1380-1384.

[7] 张若琳,孟晖,连建发.基于 GIS 的中国泥 石流易发性评价, 成都理工大学学报 (自然科学版) ,2013,40(4):379-386.

[8] 邹强,王青,刘延国.基于GIS与Logistic模 型的公路泥石流易发性分析,水土保持 通报,2014,34(3):185-189.

[9] Gao H, Liu J F. The review of methods for debris flow hazard assessment. Proceedings of the 7th Annual Meeting of Risk Analysis Council of China Association for Disaster Prevention (November 4-6, 2016, Changsha, China) pp. 1951-6851.

[10] Pan A P. A study on residents' risk perception in abrupt geological hazard. Journal of Analysis and Crisis Response, 2012, 2(1), 44-55.

[11] Zhang C Y, Wang J Z, Hu Y J, Zhang W.
Research on construction of major drainage system for urban area of Shijiazhuang. Journal of Risk Analysis and Crisis Response, 2015 5(4), 246-256.

[12] 孟兴民,陈冠, 郭鹏, 等. 白龙江流域滑坡 泥石流灾害研究进展与展望, 海洋地质 与第四纪地质,2013,33(4):1-15.

[13] 刘传正, 苗天宝, 陈红旗, 等. 甘肃舟曲 2010年 8 月 8 日特大山洪泥石流灾害的 基本特征及成因, 地质通报,2011, 30(1): 141-150.

[14] 赵伟华,黄润秋,赵建军,等.强震条件下 碎裂岩体崩塌机理及崩塌后壁对堆积 体稳定性影响研究, 工程地质学报, 2011,19(2):205-212.

[15] 吴永,何思明,裴向军, 等.震后沟道泥石 流启动条件-松散堆积体雨中失稳的水 力学机制分析, 岩土力学,2012, 33(10): 3043-3050.

[16] 康志成, 李焯芬, 马蔼乃, 等. 中国泥石流 研究,科学出版社,北京,2004.

[17] 彭建,李丹丹,张玉清. 基于GIS和RUSLE 的滇西北山区土壤侵蚀空间特征分析以云南丽江县为例, 山地学报, 2007,25(5):548-556.

[18] 刘希林, 庙成, 田春山.区域滑坡和泥石流 灾害两种危险性评价方法的比较分析, 防灾减灾工程学报, 2017,37(1):71-78.

[19] 王高峰,高幼龙,王洪德, 等.基于图幅调 查的六盘山镇滑坡易发性研究, 科学技 术与工程,2017,17(36):22-29.

[20] 柳金峰,黄江成, 欧国强, 等.甘肃陇南武 都区泥石流易发性评价, 中国地质灾害 与防治学报,2010,21(4):8-13. 